\title{
The Significance of Assessing Money Laundering Risk as a Part of Auditing Operations
}

\author{
By Sonja Cindori* \\ Tajana Petrovic ${ }^{\dagger}$
}

\begin{abstract}
In addition to the ever attractive financial sector, the effect of globalisation on the development of money laundering and terrorist financing process has gradually been including the non-financial sector, namely, independent legal professions. The specific nature of the auditing profession, providing a full insight into financial operations and analysis of individual business entities' transactions, can result in a detection and prevention of money laundering, theft and other criminal activities. Auditor independence is the auditor's main tool when performing basic auditing tasks, controls and reporting on suspicious transactions in accordance with the adopted code of ethics. The risk-based approach is omnipresent in auditing even though auditors often focus on low-risk business entities. However, some business processes result in events and circumstances which increase the risk of fraud and errors. The risk of failure in detecting fraud is significantly greater than the risk of failure in detecting material misstatement that is objectively present in financial statements, due to the fact that fraud is deliberately misleading statement, while error is unintended failure, most commonly caused by negligence. Due to the implementation of international standards into a national framework, focusing on permanent training and control of the non-financial sector, the auditing profession has earned its role of "gatekeeper" in the anti-money laundering and counter-terrorist financing system.
\end{abstract}

Keywords: money laundering, terrorist financing, auditor, risk, suspicious transactions, fraud

\section{Introduction}

The issue of laundering of money obtained by criminal acts is not a new phenomenon in the society. It is a well-known fact that money laundering aims at covering up illegal sources of income and attempting to legalise them. Initial attempts at money laundering covered simpler procedures and they were based on the banking and non-banking financial sector. Globalisation influenced the development of more complex money laundering processes which started to include the non-financial sector, resulting in time in money laundering prevention mechanisms covering an increasing number of obliged entities such as auditors, external accountants and tax advisors, notaries and other independent legal professionals

\footnotetext{
* Associate Professor, Faculty of Law, University of Zagreb, Croatia.

${ }^{\dagger}$ Senior Advisor, BSc in Economics, Ministry of Finance, Tax Administration, Regional Office of Northern Croatia, Croatia.
} 
In mid-19th century, the professional category of accountants and auditors was created as a specialized group of people dealing with the prevention and detection of actual or possible frauds and errors in financial transactions of business entities. Their role was not just limited to investigation as it also included assessment of possible risks and a guarantee of internal control mechanism efficiency. According to Petrascua and Tieanub (2014) at the end of the 20th and in the beginning of the 21 st century, auditors became crucial for the good functioning and efficiency of business entity management, being able to prevent and detect money laundering scenarios, thefts and other criminal activities.

Auditing is a procedure in which financial statements and consolidated financial statements of auditees, as well as data and methods used in the preparation of such statements are checked and evaluated in order to provide a professional and independent opinion on whether the auditee's financial status, business results and money flows are objective and truthful. The basic types of audit include internal audit, external audit, business audit, financial statements audit, commercial audit and state audit (Tušek and Žager, 2007:71-76).

The same authors state that it is important to point out the basic auditing principles, such as the principle of legality, professional integrity, independence, expertise and competence, responsibility, documentation and the principle of fair reporting. External auditor independence is crucial when considering reliability of accounting data and reporting on suspicious transactions. It is a key tool which auditing professions use to prove that auditing and control tasks are done in accordance with the adopted code of ethics.

The internal and external audits are connected and mutually reinforcing. The latter is proven by initiating an external audit procedure using analysis, verification and evaluation of the reliability of internal controls. Well-organised systems of internal control require a lesser number of tests and checks by the external auditor.

This paper focuses on external audit, but also partially covers internal audit because of the connection with everyday financial activities and the activities of money laundering prevention. Due to the specific nature of auditing work, which enables auditors to have access to the complete financial operations and detailed analysis of individual transactions of a business entity, auditing has become a platform for the detection of suspicious transactions.

The introductory part of the paper shows the implementation of EU legislation into Croatian legislation where independent legal professions have been regarded as the "gatekeeper" from the 1990s. A risk-based approach, combined with audit risk, lays the foundation for auditors in the prevention of money laundering and terrorist financing. Considering their importance, inherent risk, control risk and risk of non-detection or detection risk will be further described. The aim of the paper is to show the ever more significant role of the auditing profession which can detect suspicious transactions and prevent money launderers from using auditing profession to achieve their goals. The final part of the paper will show statistics of suspicious transaction reports by the auditing profession for the period from 2011 to 2014. Although reporting of suspicious transactions by the auditing profession in most countries is negligible, 
statistics indicate that there is a potential that can be achieved through the legislative foundation and permanent training of obliged entities in this sector which would result in a larger number of reports of suspicious transactions as an important step in combating money laundering and terrorist financing.

\section{Implementation of Directives covering Independent Legal Professions into Croatian Legislation}

The fight against money laundering and terrorist financing in the European Union has been in progress for a long time (from 1991) as evidenced by four counter-money laundering directives (Directive 91/308/EEC, Directive 2001/97/EC, Directive 2005/60/EZ, Directive 2015/849/EU). The first three have already been implemented into Croatian legislation and the last one is to be implemented two years after its entry into force. At first, directives focused on the banking sector and non-banking financial sector. Once national laws were harmonised and preventive measures in the banking and non-banking financial sector (i.e. insurance companies, investment firm, pension companies) strengthened, the focus of money laundering prevention logically shifted to the non-financial sector (auditors, external accountants and tax advisors, notaries, lawyers).

Directive 91/308/EEC (hereinafter: the First Directive) had two primary goals: to request Member States to introduce the prohibition of money laundering and improve cooperation amongst Member States in investigation and criminal prosecution of money laundering cases by 1 January 1993 (Cindori, 2010:71). The First Directive focused on the financial sector, with independent legal professions just being generally mentioned in its Article 12, keeping this sector out of its actual reach.

Directive 2001/97/EC (hereinafter: the Second Directive) expanded its reach and application of anti-money laundering rules to independent legal professions. Therefore, Pedić (2010) states that obligations of individual professions were further elaborated by the Second Directive, but its provisions applied to lawyers and notaries only when they helped their clients with planning and execution of transactions or acted on behalf and for the client in financial transactions or transactions regarding real estate transactions.

Directive 2005/60/EC (hereinafter: the Third Directive) is much more comprehensive than the first two Directives and one of its main characteristics is the risk-based approach.

Due to their special status, independent legal professions were subject to exceptions, which were also included in the Third Directive. Articles 9 and 23 of the Third Directive stipulated that notaries, independent legal professionals, auditors, external accountants and tax consultants who, in the course of determining the legal status of their clients, work on their clients' defence or representation in court proceedings or in connection with legal proceedings (including counselling on initiating or avoiding proceedings), were not required to conduct client due diligence nor inform the competent authority of the 
information obtained. Information in question can be received or given before, during and after the specified proceedings.

Directive 2015/849/EU (hereinafter: the Fourth Directive) improves the present risk-based system by intensifying measures of targeted prevention and improves efficiency by creating a global risk-oriented system. The Fourth Directive confirms exceptions for independent legal professions from the Third Directive in Articles 13 and 34. The Fourth Directive expands the circle of obliged entities, introduces a broader definition of a politically exposed person, strengthens transparency of actual owners, focuses more on issues of data protection and further strengthens the role of senior management with regard to the obliged entities' compliance.

The Croatian Anti-Money Laundering and Terrorist Financing Act obliges members of independent legal professions to implement measures aimed at preventing and detecting money laundering and terrorist financing while performing their duties. Exceptions stipulated by the Third Directive, and confirmed by the Fourth Directive, have been implemented into Croatian laws. However, it is important to emphasise the obligation of independent professions to report to the Anti-Money Laundering Office if the client asks for consulting regarding money laundering or terrorist financing, either immediately or within three days.

\section{Legislation on Audit Implementation}

One of the first measures adopted in EU on audit harmonisation was the so-called Eighth Directive (Directive 84/253/EEC). Due to some provisions being incomplete and certain shortcomings being detected, the new Directive 2006/43/EC was adopted. When compared to the previous Directive, parts about the implementation of public oversight of the auditing profession and quality assurance of work performed by auditing firms, independent auditors and statutory auditors underwent the most substantial changes.

Directive 2014/56/EU introduced new terms such as professional ethics and scepticism into the legislation. When performing a statutory audit, auditors must maintain professional scepticism throughout the audit, which means that they need to recognise a possibility of a material misstatement, due to facts or behaviour indicating irregularities (including fraud or error), could exist. These actions are necessary regardless of the statutory auditor's or the auditing firm's past experience of the honesty and integrity of the audited entity's management and of the persons charged with its governance.

The International Standards on Auditing provides a framework for performing financial statement audit and their goal is to promote audit implementation quality, which is also the reason why they are regularly amended. In Croatia, the Croatian Chamber of Auditors is the institution which translates, interprets and publishes the standards on the Chamber's website. International auditing standards relevant for analysing auditing subject matter are auditing standards ISA 240 (The Auditor's Responsibilities Relating to Fraud in an Audit of 
Financial Statements), ISA 250 (Consideration of Laws and Regulations in an Audit of Financial Statement) and ISA 260 (Communication with Those Charged with Governance), which refer to general principles and instructions regarding the responsibilities and actions of the external auditor when considering errors and frauds in financial statement auditing.

\section{Risk-based Approach}

The audit procedure starts with risk assessment, which is performed from the audit planning phase until the final audit phase. International auditing standards regarding risk assessment and reaction to risk assessment are ISA $300-399$.

In its introductory provisions, the Fourth Directive specifies that the risk of money laundering and terrorist financing is not the same in every case, therefore, recommending that a holistic, risk-based approach be used. It involves the use of evidence-based decision-making in order to target the risks of money laundering and terrorist financing. Obliged entities must establish policies, controls and procedures to mitigate and manage effectively the risks of money laundering and terrorist financing which shall be proportionate to the nature and size of the obliged entities.

It has been noted (Esoimeme 2015:14) that the introduction of risk categorisation is a potential risk management strategy as it enables subjecting clients to proportional controls and checks. Risk criteria most commonly used are state or geographic risk, client risk and product or service risk.

When performing audits, auditors' work is mostly focused on low-risk businesses and checks of the accounting correctness of business events, entities' risk as well as checks of tax and legal business aspects.

Auditors are not only regularly exposed to financial data of enterprises, but they also possess knowledge and expertise in the design and control of various internal operations and activities. However, they do not need to design special auditing procedures in order to identify and keep track of illegal activities they are expected to be aware of the mere possibility of such activities. The above confirms that the assessment of audit risks is important for audit implementation (Reuter and Truman 2004:62-63).

\section{Audit Risks}

According to Tušek and Žager (2007) audit risk is a probability that the auditor will fail to detect a material misstatement that exists in financial statements and it is assessed in the planning, implementation and evaluation of audit result phases. A preliminary audit risk assessment consists of an inherent risk, control risk and detection risk.

It is stated (International Standard on Auditing 200 2009:89) that inherent risk refers to the susceptibility to misrepresent an account balance or a type of transaction which may be significant (individually or together with 
misrepresentation of other balances or transactions), implying the absence of adequate internal controls. Tušek and Žager (2007) clame auditing firms assess inherent risk in the range between $50 \%$ and $100 \%$, which means that large, decentralised and diversified organisations lacking appropriate control will be assessed as having a higher inherent risk. One of the factors when assessing inherent risk refers to unusual and complex transactions which result in a higher probability of errors in financial statements.

Control risk is the risk that a misstatement, which might appear in the account balance or transaction type, might not be prevented in time or detected by the accounting system and internal control system, while detection risk refers to the risk that auditor's evidence procedures will fail to detect substantial misstatements in account balance or transaction types (International Standard on Auditing 200 2009:89).

Even though auditors cannot influence inherent and control risks, they can achieve an acceptable level of detection risk by performing an appropriate type and scope of direct procedures for verifying objectivity of information in financial statements. The above has an effect on the total audit risk reduction (Tušek and Žager 2007:189).

\section{Auditor's Role in detecting Suspicious Transactions}

Auditors, as part of the non-financial sector, play a very important role in the detection of suspicious transactions, especially in conducting client due diligence and auditing of financial statements, which is why they are considered to be an important element in implementation of money laundering and terrorist financing prevention measures.

Fraud is one of the increasingly, more obvious, forms of business risk at all organisation levels. The risk of potential fraud is pronounced in recognising revenue and trade receivables, and in inventories. Therefore, according to Mališ, Tušek and Žager (2012) the auditor should assume the possibility of a great risk of material misstatement and fraud during the audit of revenue beforehand as overstatement or understatement of income or overstatement of inventory are among the most common forms of fraudulent financial reporting.

Petrascua and Tieanub (2014) argue there are circumstances or events which increase the risk connected to fraud or errors. Such circumstances comprise aspects related to the management's integrity and competence, internal or external unusual conditions that influence the activity of the economic agent, unusual transactions, or problems concerning obtaining sufficient and appropriate audit proof.

Lately, the emphasis has been placed more on the preventive actions of the internal audit, that is, on providing help and support to the management in anticipating future risks and proposing such a system of internal control which would promptly overcome risks (Mihajlović 2016:50). 


\section{Internal Auditor's Role in the Process of Prevention and Detection of Fraud}

Internal audit can significantly contribute to its own main goals by providing its opinion regarding efficiency of internal controls, suggestions for their improvement and information regarding the latest techniques and methodologies for fraud detection to management. When performing testing of internal control functioning, individual transactions are checked in detail and risk assessment ensures that checks are aimed at important elements of individual transactions.

It has been noted (Mahaček et al. 2015:56) that risk assessment plays a significant role in forming opinion of internal auditors who describe the existing status and explain what the system might be like and what the risks might entail should specific actions not be taken. The report should also include recommendations for reduced exposure to risks, enabling auditors to conclude that internal audit is an extension of management.

However, the internal auditor can possess the knowledge granted to authorised persons for the detection and investigation of business fraud in various for-profit and non-profit organisations. Crnković (1997) has claimed that the internal audit procedure, even when performed in accordance with due diligence standards, does not necessarily result in detecting fraud. It is important that auditors give warnings for incorrectly performed jobs, errors, inefficiency, conflict of interest and other criminal activities. In order to prevent and detect fraudulent activities, it is crucial to implement measures and activities such as raising awareness about combating fraud, strategy development, use of IT programs for detecting fraud and appropriate employee training.

\section{External Auditor's Role in the Process of Prevention and Detection of Fraud}

The evaluation of a business entity's internal control system is an integral part of the overall financial statement audit process. It is important to specify that the external auditor must assume that a business entity's internal audit is not entirely independent.

International auditing standards which represent general principles and instructions regarding responsibility and actions of the external auditor when considering errors and fraud in financial statement auditing are ISA 240, ISA 250 and ISA 260.

The auditor is not, and cannot be, responsible for preventing fraud or error, yet just a mere fact of auditing can prevent them. However, Tušek and Žager (2007) indicate that the external auditor bears full responsibility for expressing an opinion on the accuracy and fairness of the financial statements and whether, and to what extent, the results of the business entity's internal auditor will be used depends on the external auditor's professional judgement.

Acquiring knowledge about a business entity's operation is an ongoing procedure through which the auditor obtains basic information. During a continuous auditing commitment, a detailed study of and familiarisation with 
the company is not required, in contrast to the performance of an audit on a new company.

The Anti-Money Laundering and Terrorist Financing Act (hereinafter: the Act) stipulates that upon establishing a business relationship with a customer, subject to the mandatory audit of annual accounting statements, an auditing firm and an independent auditor may conduct a simplified customer due diligence, save for instances where there is reason for suspicion of money laundering or terrorist financing associated with a customer or circumstances of an audit.

In order to make an overview of company policies and procedures, as well as its environment (including internal controls), when performing analytical procedures, the auditor should consider unusual or unexpected relationships that may indicate risks of misstatement due to fraud. Analytical procedures may be helpful in determining the existence of unusual transactions or events, as well as amounts, indicators and trends that may indicate areas affecting the financial statements and the audit (Soltani 2009:544).

Although complex and unusual transactions have always been seen as a risk factor, they have lately been gaining in importance. According to ISA 550 (Related parties, entails the disclosure of related parties in the financial statements) the auditor must obtain names of all the related parties and determine and study all significant transactions with related parties and pay special attention to transactions in unusual circumstances.

When the auditor notices a possibility of an error or fraud and establishes that such an error or fraud can have an effect on financial statements, bearing in mind the previous risk assessment, the auditor is required to undertake additional audit procedures. If that still does not resolve doubts regarding a significant error or fraud, the auditor, in cooperation with the management, needs to determine whether the effect of fraud was corrected in the financial statements, and how that will affect the auditor's report (Mališ et al. 2012:423).

The auditor's opinion is the final result of the audit. A qualified opinion, disclaimer of opinion or adverse opinion are modified statements which significantly deviate from the standard positive report. An adverse opinion is issued if the auditor discovers that the fraud or error has a significant effect on financial statements and they were not correctly represented. A qualified opinion or a disclaimer of opinion are issued if there is not enough evidence regarding whether a fraud or error has a significant effect on financial statements. Documents based on which the auditor's opinion is expressed (evidence and prepared working documents) have to be complete and detailed so they could be used to reconstruct the overall audit process.

It is noted (Salem 2012:219,227) that frauds in companies are most commonly detected by accident. Companies can have excellent internal control systems which are often not efficient primarily because the management ignores them or colludes in circumventing them. The management, which should develop a system of appropriate internal controls, bears primary responsibility for preventing or detecting fraud. Such a system will not necessarily remove all risk of fraud, but it will vastly reduce it. External auditor has to be aware that a 
possibility of a fraud exists, which means that the external auditor should primarily focus on true presentation of financial statements regarding the financial position and results of business entities.

\section{Obligations of Suspicious Transactions Reporting}

By applying mandatory measures to enforce the law, independent auditors and auditing firms, when performing their professional activities, can and have to recognize and point to the risks or certain circumstances under which the audited entity may be found in the role of a money laundering channel. The analysis of the audited entity can be applied to a business relationship with a risky client and/or a risky transaction of the audited company.

Obliged entities must notify the Anti-Money Laundering Office of suspicious transactions by telephone, fax or in some other way before the transaction is executed, and after the transaction execution, the notification will be submitted in the manner prescribed by the Ordinance on the manner and terms of notifying the Anti-Money Laundering Office of suspicious transactions and persons, and the keeping of records by lawyers, law firms, notaries, auditing firms and independent auditors as well as legal and natural persons providing accounting and tax advisory services. If the client asks for advice on money laundering or terrorist financing, the notice must be delivered immediately, and no later than in three days.

Table 1. The Total Number of received Financial Intelligence Unit (FIU) Reports regarding suspicious Transactions by Auditors in the Period from 2011-2014

\begin{tabular}{|l|c|c|c|c|}
\hline Country & $\mathbf{2 0 1 1}$ & $\mathbf{2 0 1 2}$ & $\mathbf{2 0 1 3}$ & $\mathbf{2 0 1 4}$ \\
\hline Austria & 1 & 2 & 1 & 3 \\
\hline Armenia & 0 & 0 & 0 & 0 \\
\hline Belgium & 18 & 23 & 48 & 68 \\
\hline Italy & - & 5 & 10 & 16 \\
\hline Croatia & 11 & 1 & 5 & 2 \\
\hline Slovenia & - & - & 2 & 1 \\
\hline Serbia & 0 & 4 & 5 & 9 \\
\hline Tunisia & 1 & 0 & 0 & 4 \\
\hline
\end{tabular}

Source: Authors' work based on Croatian FIU reports and FATF reports

The statistics of suspicious transaction reports is presented differently by different states. Reports applying only to the auditing profession are presented by Belgium, Italy and Serbia, while Armenia, Slovenia and Tunisia present them together with the accounting profession. Austria presents data as the total sum of suspicious transactions reported by public accountants and tax consultants, and Croatia as transactions of natural persons performing accounting services and tax consultancy services. Data from 2011 refers to independent legal professions together. It is evident that the auditing occupation rarely reports suspicious transactions, which can point to inadequate auditor training, 
limited independence or confirmation of the premise that auditors work with low-risk businesses.

It is also important to consider the fact that the specified statistics show countries with different customs, cultures and national laws, yet the prevention of money laundering and implementation of international regulations into national laws is at least approximately equal. However, regardless of the above, a great discrepancy in numbers of reports of suspicious transactions among the studied states has been detected. Belgium leads the way in the number of reports, Italy lags behind, while other countries have made only few reports. Despite the large number of reports, the evaluation process has found that Belgian prevention system control programmes were established without performing individual risk assessment for different professions and without referring to the risk in individual sectors. Several major shortcomings regarding the coordination of prevention of money laundering and terrorist financing need to be pointed out: failure of control and self-regulatory bodies to include major risks of money laundering and terrorist financing into control policies, insufficient detection of money laundering risks and incomplete dissemination of non-confidential risk assessment results to financial and nonfinancial institutions, thus slowing down their processing in internal procedures.

\section{Acknowledgements}

This work has been supported by the Croatian Science Foundation under the project number UIP-2014-09-5933.

\section{Conclusion}

By studying international and national legislation, it is evident that the obligations of the auditing profession in the Republic of Croatia are in line with international standards governing their initial activities, but also with laws on the prevention of money laundering and terrorist financing. It is also important to mention the Third Directive which provided a more detailed elaboration of auditors as the obliged entities in money laundering prevention and provided one of its basic characteristics - a risk-based approach.

Risk assessment has increasingly become a crucial activity in auditing, especially in the part regarding audit planning. By imposing reporting obligations onto the auditing profession, the legislator has achieved an additional goal of controlling criminal activities. It is important to emphasize the importance of professional and continuing training of auditors on the mentioned issues in order to minimize possible failures to detect suspicious transactions. Apart from having to be sufficiently trained and competent, auditors should be independent and responsible when reporting detected suspicious activities of observed business entities. Despite the good legislative foundation, the statistics of 
suspicious transaction reports in most countries is poor, but the ultimate objective is to raise awareness regarding the discussed issues.

\section{References}

Anti-money laundering and terrorist financing law (Official Gazette No. 87/2008, 25/2012).

Audit act (Official Gazette No. 146/2005, 139/2008, 144/2012).

Cindori, S (2010) Sustav sprječavanja pranja novca. Faculty of Law, University of Zagreb, Zagreb.

Crnković B (1997) Interna revizija, Mikrorad d.o.o., Zagreb.

Directive 91/308/EEC on prevention of the use of the financial system for the purpose of money laundering (OJ L 166, 28 June 1991, 77 - 83).

Directive 2001/97/EC amending Council Directive 91/308/EEC on prevention of the use of the financial system for the purpose of money laundering (OJ L 344, 28 December 2001, 76 - 82).

Directive 2005/60/EC of the European Parliament and of the Council on preventing the use of the financial system for money laundering and terrorist financing $(\mathrm{OJ} \mathrm{L}$ 309, 25 November 2005, 15-36).

Directive 2006/46/EC of the European Parliament and of the Council of 14 June 2006 amending Council Directives 78/660/EEC on the annual accounts of certain types of companies, Council Directive 83/349/EEC on consolidated accounts, Council Directive 86/635/EEC on the annual accounts and consolidated accounts of banks and other financial institutions and Council Directive 91/674/EEC on the annual accounts and consolidated accounts of insurance undertakings (OJ L 224, 16 August 2006, 1 - 7).

Directive 2014/56/EU of the European Parliament and of the Council of 16 April 2014 amending Directive 2006/43/EC on statutory audits of annual accounts and consolidated accounts (OJ L 158, 27 May 2014196 - 226).

Eighth Council Directive 84/253/EEC of 10 April 1984 based on Article 54 (3) (g) of the Treaty on the approval of persons responsible for carrying out the statutory audits of accounting documents (OJ L 126, 12.5.1984, str. 20 - 26).

Esoimeme EE (2015) The Risk-Based Approach to Combination Money Laundering and Terrorist Financing. New York: Eric Press.

International Standard on Auditing 200 (2009) Overall Objectives of the Independent Auditor and the Conduct of an Audit in Accordance with International Standards on Auditing, International Federation of Accountants, New York.

Mahaček D, Bolfek B, Šakota B (2015) Uloga interne revizije u sprječavanju pogrešaka i prijevara računalne obrade podataka, Oeconomica Jadertina 1: 48 64.

Mališ S, Tušek B, Žager L (2012) Revizija - načela, standardi, postupci. Hrvatska zajednica računovođa i financijskih djelatnika, Zagreb.

Mihajlović SLJ (2016) Ocena budućih rezultata poslovanja i preventivna uloga interne revizije u upravljanju rizikom. Proceedings of Forensic audit (Belgrade, Serbia, December 10-11, 2015), Belgrade, 48 - 55. Retrieved from http://www.forensicaudit.org/uploads/1/4/6/3/14634014/zbornik_forenzicka_revizija.pdf.

Ordinance on the manner and terms of notifying the Anti-Money Laundering Office of suspicious transactions and persons, and the keeping of records by lawyers, law firms, notaries, auditing firms and independent auditors as well as legal and natural 
persons providing accounting and tax advisory services (Official Gazette No. 1/2009, $153 / 2013)$.

Pedić Ž (2010) Nefinancijski sektor i samostalne profesije u kontekstu sprječavanja pranja novca, Zbornik Pravnog fakulteta Sveučilišta u Rijeci 31(1): 617 - 642.

Petrascua D, Tieanub A (2014) The role of Internal Audit in Fraud Prevention and Detection, Procedia Economics and Finance 16 (Sibiu, Romania, May 16-17, 2014), Romania, 489 - 497. Retrieved from http://www.sciencedirect.com/scien ce/article/pii/S2212567114008296.

Reuter P, Truman MB (2004) Chasing dirty money. Institute for International Economics, Washington, DC.

Salem MSM (2012) An Overview of Research on Auditor's Responsibility to Detect Fraud on Financial Statements, The Journal of Global Business Management 8 (2): 218- 229. Retrieved from http://connection.ebscohost.com/c/articles/84953 110/overview-research-auditors-responsibility-detect-fraud-financial-statements.

Soltani B (2009) Auditing: An International Approach, Philadelphia, Pennsylvania: Trans-Atlantic Publications, Inc.

Tušek B, Žager L (2007) Revizija, Hrvatska zajednica računovođa i financijskih djelatnika. Zagreb.

Web sources

FIU Report Croatia

http://www.revizorska-komora.hr/pdf/MRevS/1_KB-za-CIP-124.pdf visited on 20 September 2016

http://www.mfin.hr/adminmax/docs/GODISNJE\%20IZVJESCE\%20O\%20RADU\%2

OUREDA\%20ZA\%202014.pdf visited on 23 September 2016

http://www.mfin.hr/adminmax/docs/Godisnje\%20izvjesce\%20o\%20radu\%20Ureda\% 20za\%202013.\%20godinu.pdf visited on 23 September 2016

http://www.mfin.hr/adminmax/docs/GODISNJE\%20IZVJESCE\%202012.-28.08.pdf visited on 23 September 2016

http://www.mfin.hr/adminmax/docs/Godisnje\%20izvjesce\%20o\%20radu\%20Ureda\% 20za\%202011.\%20godinu.pdf visited on 23 September 2016

FIU Report Slovenia

http://www.uppd.gov.si/fileadmin/uppd.gov.si/pageuploads/deloUrada/letno_porocilo _2014.pdf visited on 23 September 2016 
FIU Report Austria

http://www.fatf-gafi.org/media/fatf/documents/reports/mer4/MER-Austria-2016.pdf visited on 23 September 2016

FIU Report Tunisia

http://www.fatfgafi.org/media/fatf/documents/reports/merfsrb/Tunisia_MER_2016_E N. pdf visited on 23 September 2016

FIU Report Serbia

http://www.fatfgafi.org/media/fatf/documents/reports/merfsrb/MONEYVAL(2016)2 MER_Serbia_en.pdf visited on 23 September 2016

FIU Report Italy

http://www.fatf-gafi.org/media/fatf/documents/reports/mer4/MER-Italy-2016.pdf visited on 23 September 2016

FIU Report Armenia

http://www.fatf-gafi.org/media/fatf/documents/reports/merfsrb/MONEYVAL(2015)3

4_5thR_MER_Armenia.pdf visited on 23 September 2016

FIU Report Belgium

http://www.fatf-gafi.org/media/fatf/documents/reports/mer4/Mutual-Evaluation-Re port-Belgium-2015.pdf visited on 23 September 2016 
